\title{
Political Economy of Rent Seeking in Local Governance: Causes, Forms, and Responses Towards (Evidences from Adigrat Town Administration, Ethiopia)
}

\author{
Teklie Tesfamariam Berhe \\ Department of Civics and Ethical Studies, College of Social Sciences and Humanities, Adigrat University, Adigrat, Ethiopia
}

Email address:

teklietesfa27@gmail.com

\section{To cite this article:}

Teklie Tesfamariam Berhe. Political Economy of Rent Seeking in Local Governance: Causes, Forms, and Responses Towards (Evidences from Adigrat Town Administration, Ethiopia). Journal of Public Policy and Administration. Vol. 4, No. 3, 2020, pp. 51-60.

doi: $10.11648 /$ j.jppa.20200403.14

Received: August 7, 2020; Accepted: August 21, 2020; Published: September 3, 2020

\begin{abstract}
Irrespective of the nature of a state, the issue of rent seeking remains ubiquitous. This paper assesses the prevalence of rent seeking from local governance perspective providing a focus on the major causes, forms and the efforts made in Adigrat Town. In so doing, the study has used both quantitative and qualitative research methodologies. Primary and secondary data sources were also utilized. Accordingly, the sluggish form of public services, lack of institutionalized practices, prevalence of mutual mistrusts, materialistic and self-centered motives, and embedded patrimonial relations have unleashed the practices of rent seeking in the Town. Bureaucratic corruption, lobbying practices, bribery, and actions of collusive interests were endemic forms of rent seeking prevailed in the Town. In connection, rent seeking situations where individuals negotiate over exclusive benefits and favor-seeking groups capture the public offices were common. Remedies of mainstreaming rent seeking as a public agenda, regular evaluation on performances, involvement of stakeholders in decision making, enforcement of legal measurement, introduction of ICT, and awareness creation were found too nascent. Thus, the respective public sectors should acquaint with anti-rent seeking strategies including meritocracy, party and government roles delineation, rebuilding the social capital, independent law enforcement, and delivering ICT-backed services.
\end{abstract}

Keywords: Rent Seeking, Corruption, Institution, Governance, Town

\section{Introduction}

The political economy of rent seeking had been reflected in the ancient political and ideological movements in history. The ancient civilizations, Roman Empire, the $16^{\text {th }}-18^{\text {th }} \mathrm{c}$ Mercantilist Western Europe, ideology of socialism, and the state capitalism were not independent of the culture of rent seeking [5]. The intensified prevalence of rent seeking in the socio-economic and political systems of countries made the issue acquire augmented academic attentions and discussions [28]. The recent form of labeling and usage of the term however belongs to Anne. O. Krueger [34, 22]. Krueger has attempted to look at the political economy of rent seeking society taking the empirical evidences from Turkey and India to explain the resources expended by private sectors in capturing the privileged exports and import-licenses influencing government officials in which the competitive rent tended to precipitate unnecessary waste of talents, time, money, energy and efforts which otherwise could be productive [26]. For Virginian Public Choice School, rent seeking is inherent consequence of government intervention in the market system distorting the market equilibrium [20, 28]. Rent-seeking also implies the resources expended by competing interest groups in order to control and secure returns higher than they could earn in the dearth of government special protection [Rowley, 2000 cited in [28]. In simple words, rent-seeking refers to the attitudes and behaviors of individuals to derivate incomes without producing necessary value to the socio-economic and political environment [16]. The resources which could be used in rent seeking process are costs because they are being utilized to distort the fair benefit distribution [22].

Rents and rent-seeking are omnipresent as far as there are rights within a given society [3, Medema, 1991 cited in [16]. 
Nevertheless, due to the widespread presence of weak social, economic and political institutions, the adverse impact of rent seeking behaviors has reached its pinnacle in developing countries [13, 28]. In Less Developed Countries (LDCs) where there are fragile rule of law apparatus, weak check and balance system, volatile institutional structures, spoiled social capital, and non-insulated bureaucracy, the political economy of rent seeking prevails. The typical forms of rent seeking behaviors range from subsidizing the campaign of legislatures, bribery, lobbying, bureaucratic corruption, to political violence $[23,16,31]$. Thus, LDCs are identified by rampant cliental and patrimonial networks tied with thick thread for years breeding rent seeking activities [21]. Indisputably, African countries are characterized by the existences of political patronages, patrimonial linkages, dissatisfied and politically partisan civil servants, and unproductive private sectors in which all together exacerbate the possibility of rent seeking perils $(3,11,25)$. Many African countries including Ethiopia are identified by a production and distribution scheme which is captured by a few organized groups. The interest groups in collaboration with the political leadership enjoy exclusive benefits protected by the latter as reciprocity to the political support provided [9, 1]. In Ethiopia, the emergence of rent seeking attitudes and activities is traced back to the Abyssinnian and Imperial regime. Unfortunately, in the current regime, the overall development efforts are also being entangled by the rent seeking trap thereby it needs further innovative institutional remedies [6]. According to [19], the coupled issues of undeveloped social values and the practice that rent seeking and corruption are legally and morally excusable activities are making the fight against wasteful rent seeking behavior in Ethiopia formidable. For that reason, rent seeking has been precipitating unproductive investments, government legitimacy crisis, and weakening the culture of working hard in Ethiopia [8].

As a matter of commitment, the government in its five years (2009/10-2014/15) Growth and Transformation Plan I (GTP-I) stated that concerted actions to fight against rent seeking and public corruption are to be undertaken [32]. Likewise, GTP II (2015/16-2019/2020) has already also identified and recognized socially wasteful rent seeking and corruption as all-encompassing challenge to the political economy of development of the state. Furthermore, senior Ethiopian People's Revolutionary Democratic Front (EPRDF)'s top officials, at different occasions proclaimed that concerned citizens should strengthen their participation in the fight against rent seeking working in tandem with the anti-corruption coalitions. Among others, public sectors are hence expected to set anti-rent seeking strategy to ensure the principles of accountability and transparency in their working environment $[8,35]$.

In the same parlance, it has been noted that rent seeking practices are the realms of expanding transparency initiatives, structuring sound institutional maneuvers, and massive community participation in decision making processes. Specifically, the reformist leaders in the current ruling party
[Prosperity Party] has been proclaiming that corrupt and rent seeking practices are intolerable in the land of Ethiopia. Similarly, the National Regional State of Tigrai's higher officials have been declaring that adequate structural and institutional reforms are being undertaken so that create rent seeking condemning society. Despite the institutional and structural changes in the administrative apparatuses, there are formidable challenges faced the governance processes. As a consequence, Transparency International has clearly stated that still the country is ranked among both the grand and petty corruption-ridden countries. It is revealed that Ethiopia ranks 135 out of 180 countries in Corruption Perceptions Index report of Transparency International. Most particularly, although it has been indicated that the energy, police, judiciary, land administration, and social services are notoriously known by embedded problems associated with rent seeking, the local government level-based rent seeking causes, forms, and respective measures used haven't been incorporated in literatures hitherto.

Some empirical researchers have been conducted on the issue of corruption in Ethiopia. To mention a lot, Gashaw etal (2015), Tesfaye (2007), Transparency International (2014 \& 2018), Plummer (2012), Befekadu (2013), Gudeta (2013), and Alemu (2013) have tried to emphasize on the areas of consequences of corruption, prevalence of corruption, political corruption, diagnosing corruption, and national efforts against corruption. All of the aforementioned studies have concentrated merely on the nature and prevalence of corruption in Ethiopia. Despite the overall issue of corruption has been relatively existed as the study point of the previously undertaken research works, the existing causes, forms and responses towards political economy of rent seeking remain scientifically unstudied relying on local governance's primary evidences. In congruent, Adigrat Town administration is identified as the rent seeking practice ridden local government where different forms of bad governance and popular complaints for good governance are being recorded due to the rampant rent seeking practice over time. Thus, this paper has flashed light on the causes, forms and initial efforts being made against rent seeking in the local governance of Adigrat Town.

\section{Objectives of the Study}

1) To identify the major causes of rent seeking practices in the study area.

2) To indicate the forms of rent seeking practices prevailed in the study area.

3) To assess the efforts being made to minimize rent seeking practices in the study area.

\section{Research Methodology}

\subsection{Data Type and Sources}

The data types of this research are qualitative and quantitative in nature. [33] have marked that the world's 
issues can be viewed via both testing the existing theories and developing new realities observed in the societal settings. A scientific research is the one which avoids the false dichotomy reflected in the process of selecting research paradigms for both qualitative and quantitative approaches can best advance the reliability and validity of the research in tandem [33]. The data sources of the study revolve around both primary and secondary sources.

\subsection{Research Strategy and Design}

The research has been approached through both qualitative and quantitative strategies. Pertaining to the research design, the case study of Adigrat Town been used making it as a unit of analysis. And cross sectional survey has been conducted to assess the existing nature of rent seeking prevailed in the local government at a point of time. Cross sectional survey design was utilized due to the reason that it minimizes the unnecessary costs and makes research effective and manageable.

\subsection{Sampling Design and Procedures}

The research has used non-probability sampling techniques in the derivation process of the study area, respondents and key informants. Purposive sampling technique has been used in selecting public offices depending on their nature of vulnerability to the rent seeking activities. Accordingly, the purposively selected public offices to draw respondents were Peace and Administration, Municipality, Trade and Industry, Revenue Development, and Justice. Then, one interviewee from each selected offices was purposively approached taking the gender reference and relevancy in to considerations. Apart from this, interviews were conducted with purposively selected four experts from Adigrat University, Town's Public Relation office head, an expert from Federal Ethics and Anti-corruption Commission, Mekelle Branch, and Head of National Regional State of Tigrai Civil Service Bureau believed to have improved awareness on the case under investigation.

So long as questionnaires are concerned, since there was no recoded list of actual public service users in the selected public offices, the researcher conducted interview with key informants from respective public offices so that gained the average number of service users. Proportionate derivation of samples has been used to reach the average actual respective public service users. At the end, convenience sampling was used in getting the public service clients at different working times. This type of technique was employed due to the difficulty of getting the relevant public service clients at the required time and place in arranged manner. The necessary procedures used to draw respondents for the questionnaires purpose look like as follows:

Table 1. Public Sectors and Respective Service Users.

\begin{tabular}{llllll}
\hline Selected Public Sectors of Adigrat Town & Min $^{\text {a }}$ & Max $^{\mathbf{b}}$ & Ave $^{\mathbf{c}}$ & Average X 5 $^{\mathbf{d}^{2}}$ & Samples \\
\hline Peace and Administration & 5 & 15 & 10 & $10 * 5=50$ & 12 \\
Municipality & 30 & 50 & 40 & $40 * 5=200$ & 49 \\
Trade and Industry & 25 & 45 & 35 & $35 * 5=175$ & 43 \\
Revenue Development & 20 & 40 & 30 & $30 * 5=150$ & 37 \\
Justice & 10 & 30 & 20 & $10 * 5=50$ & 12 \\
Total & & & 625 & 153 \\
\hline
\end{tabular}

Source: Field Survey, 2019.

Min ${ }^{a}$ denotes the minimum number of service users per a day.

$\mathrm{Max}^{\mathrm{b}}$ denotes the maximum number of service users per a day.

Average ${ }^{c}$ denotes the average of minimum and maximum numbers.

$5^{\mathrm{d}}$ denotes the working days in a week

From this, the total population is 625 actual public service users of the selected offices. Then, Yamane's (1967) formula has been used to determine the sample size.

$$
n=\frac{N}{1+N(e)^{2}}
$$

Where, $\mathrm{n}$ is sample size, $\mathrm{N}$ is the population size and $e$ is the margin of error. Then, a 93\% confidence level and where $\mathrm{e}$ is $=0.07$ is assumed for the purpose of determining sample size of this study. Accordingly, the sample size for the study was calculated as follows.

$$
\begin{gathered}
n=\frac{625}{1+625(0.07)^{2}} \\
n=153
\end{gathered}
$$

\subsection{Data Collection and Instruments}

Cresswell (2003) recommends that the use of multiple sources of information, methods and techniques is assumed to validate the data. Hence, the primary data instruments include semi-structured questionnaires and interviews.

\subsection{Data Processing and Analysis}

Arbitrary scaling method was used to measure respondents' attitudes. Data types acquired through close-ended questionnaires filled correctly by 150 respondents were analyzed descriptively using the Statistical Package for Social Sciences (SPSS) software version 20 to produce tables and figures. A descriptive analysis method was used in the process of depicting the raw data in to a manner that made them easily understood. The data collected through openended questionnaires and interview methods were interpreted and analyzed qualitatively. Therefore, the quantitative and qualitative data types have been triangulated during the courses of analysis and interpretation. 


\section{Results and Discussions}

\subsection{Causes for Rent Seeking Attitudes and Behaviors in Adigrat Town}

As depicted in table 2, respondents were approached to rank the major causes of rent seeking in order of the importance. Accordingly, the Town administration's sluggish form of public service delivery and delayed response to the recurrent popular needs have been ranked as the principal cause for rent seeking getting the weighted scores of 625 . This is to mean that the delayed service leads the service users to illegally lobby and influence [affording some benefit] the service providers so that enjoy with quick and quality one. Then, the lack of institutionalized, inconsistent, and uncoordinated practices and decisions of the administration is ranked as second factor which led to the prevalence of local rent seeking securing the total score of 632 points. Next, the prevailing vertical (governmental line) and horizontal (societal line) mistrusts are ranked as third enforcing causes of rent seeking scoring the total weights of 623 . Besides, the individuals' entrenched tendencies to maximize materialistic desires and self-interests at the expense of the common good are ranked as fourth underlying cause fomenting rent seeking practices obtaining the total scores of 580. Lastly, the widely manifested patrimonial relations among the service providers and service users has been ranked as fifth element exacerbating rent seeking getting the weighted scores of 574 .

Table 2. Respondents Ranking on Major Causes of Rent Seeking Attitudes and Behaviors.

\begin{tabular}{|c|c|c|c|c|c|c|c|}
\hline \multirow{3}{*}{ Major causes for rent reeking } & \multicolumn{5}{|c|}{ Ranks and Assigned Weights } & \multirow{3}{*}{$\begin{array}{l}\text { Total N } \\
(\%)\end{array}$} & \multirow{3}{*}{$\begin{array}{l}\text { Finalized } \\
\text { Ranks }\end{array}$} \\
\hline & $1^{\text {st } * 5}$ & $2^{\text {nd }} * 4$ & $3^{\mathrm{rd} * 3}$ & $4^{\text {th } * 2}$ & $5^{\text {th }} * 1$ & & \\
\hline & $\mathbf{N}(\%)$ & $\mathbf{N}(\%)$ & $\mathbf{N}(\%)$ & $\mathbf{N}(\%)$ & $\mathbf{N}(\%)$ & & \\
\hline Sluggish Public Service & $90(60)$ & $35(23.33)$ & $15(10)$ & $7(4.66)$ & $3(2)$ & $150(100)$ & $1^{\mathrm{st}}=652$ \\
\hline Lack of institutionalized practice & $80(53.33)$ & $45(30)$ & $10(6.66)$ & $9(6)$ & $6(4)$ & $150(100)$ & $2^{\text {nd }}=632$ \\
\hline Prevalence of mistrust & $75(50)$ & $50(33.33)$ & $5(3.33)$ & $13(8.66)$ & $7(4.66)$ & $150(100)$ & $3^{\text {rd }}=623$ \\
\hline Material and self-interests & $70(46.66)$ & $35(23.33)$ & $17(11.33)$ & $11(7.33)$ & $17(11.33)$ & $150(100)$ & $4^{\text {th }}=580$ \\
\hline Patrimonial relations & $67(44.66)$ & $30(20)$ & $27(18)$ & $12(8)$ & $14(9.33)$ & $150(100)$ & $5^{\text {th }}=574$ \\
\hline
\end{tabular}

Source: Field Survey, 2019.... Where $N$ denotes Frequency, and\% represents Percentage.

Informants from the offices of Municipality and Trade and Industry have also added other major causes of political economy of rent seeking in the Town as follows.

Historical Antecedent: The informants pointed out that history per se is structural cause since the Ethiopian society had been governed by "service-seeking but not servicedelivering regimes" as opposed to the basic political duty of respective government. The societal perception that government bodies are "masters/served/ and the people are servant" has also been prevailing in Ethiopian society since long years ago. This precedent made the society tolerate the current rent seeking practices. The modern Ethiopian state has acknowledged different political and economic ideological trajectories in which its respective state leaders thought of them right to attain social transformation. During the Imperial regime, for instance, Ethiopia was under unitary state structure and the quagmire of feudalism where peasants were serving to the land lords and regime officials for almost nothing in return. The personal and tribal connections with the ruling class and church clergies were the only means to escape from economic and political exploitations and alienations [4]. Hence, corruption and rent seeking activities were ubiquitous in the processes of governmental services in general and in the precious resource of land administration in particular [6].

Prevailing Economic Motives: Now, the previously impoverished sects of the society need to make wealth in short cut and ensure reputation incurring less cost. In this $21^{\text {st }}$ c, citizens have started to compare their existing economic status with the undergoing global economic phenomenon so that opportunistic and greedy motives get dominance. Similarly, the undeveloped market system, and infrastructural inadequacies where individuals tend to constitute exclusive benefits have their own shares to exacerbate forms of rent seeking within the Town.

Lack of Policy Clarity and Consistency: The policy gap where there is no clear demarcation between the public sectors and market economic roles has contributed to widen the gate for rent seeking chances observed. In this regard, respondents have underlined that market based competitions over economic resources and activities are largely volatile in the Town. The local government is too interventionist in trivial economic activities to the extreme of distributing, for example, sugar and oil for food at Kebele [the lower government level] where this practice per se is highly exposed to rent seeking practices. Those local merchants who have relatives and close friends in the respective local administration offices commonly enjoy with subsidized owning and selling such monopolized and scarce resources which in turn produced inefficient resources allocations. Rent seeking attempts in bidding process, direct purchase of government properties, contract formations and other marketoriented activities have also been experienced.

In addition, associated with the continuing erosion of social capital, informants have further indicated that the socially embedded traditional Ethiopian saying which goes that "the one who didn't misuse public power for private interests gets upset when he/she deposed from" is normally being shared explicitly within the general community. It has been widely admitted by default that once a public official entrusted with a public office, as he/she inevitably seeks to exploit the public treasury so that become anti-development endeavors. That is why unnecessary tips for public services become prevalent. Today, beyond paying taxes, providing tips of any kind for a given public servant after service is 
being considered as normal practice. This common tradition undermines the very nature of government duties and services. Hence, one can assert that the fate of those public service seekers who don't have extra resources to tip government services is either to acquire less quality or denied services thereof.

Consequently, respondents have noted that the prevailing rent seeking environment has been hobbling the cultures of perseverance, consistent hard-working, mutual trusts, and confidence on the future. The same social, economic and political consequences of rent seeking and corrupt behaviors have been observed in Ambo town, Ethiopia [18]. Now, there are mushrooming orientations to deny the fact that success is only ensured through exerting ultimate efforts for there are a number of observed cases where those who did and contributed nothing positively to the economy enjoy with extraordinary lifelong benefits, which is the paradoxical event. Therefore, the political economy of rent seeking is enforcing the state to be dominantly attributed by neither developmental nor democratic but rather by crony capitalism and Neo-patrimonial situations where few privileged classes are the beneficiaries of the political and economic system despite initial state-wide official campaigns have been launched to bring about desirable change in the status quo.

\subsection{Experienced Rent Seeking Process Situations in the Town}

Table 3, succinctly shows that rent seeking situations are orders of the day in the Town. Pertinent to this, 125 (83.33\%) of the respondents have reflected special lens that institutionalized and public sector-led rent seeking situation is dominant though $19(12.66 \%)$ of the respondents disagreed that such kinds of rent seeking situations are prevailed. While 120 (79.99\%) of the respondents, still the majorities, have further agreed that there are situations where individuals are exclusively negotiating for respective private gains, $27(18 \%)$ of the respondents have disagreed. Similarly, about $120(79.99 \%)$ of the respondents have confirmed that there are covertly organized groups who exert unwanted pressures on the respective public sectors to do something in favor of the formers' interests but 26 (17.33\%) of the respondents disagreed so. Hence, all rent seeking situations are prevalent though degrees of variances are acknowledged. [23] has also found that such rent seeking situations are rampant in the developmental states of South Korea, India, Thailand, and Malaysia.

Table 3. Rent Seeking Process Scenarios Prevailed in the Town.

\begin{tabular}{|c|c|c|c|c|c|c|}
\hline $\begin{array}{l}\text { Which rent seeking process situations do you } \\
\text { agree prevalent? }\end{array}$ & $\begin{array}{l}\text { S/Agree } \\
\mathbf{N}(\%)\end{array}$ & $\begin{array}{l}\text { Agree } \\
\text { N }(\%)\end{array}$ & $\begin{array}{l}\text { Neutral } \\
\mathbf{N}(\%)\end{array}$ & $\begin{array}{l}\text { Disagree } \\
\text { N (\%) }\end{array}$ & $\begin{array}{l}\text { S/Disagree } \\
\text { N }(\%)\end{array}$ & $\begin{array}{l}\text { Total } \\
\text { N }(\%)\end{array}$ \\
\hline Rent seeking through private negotiations & $74(49.33)$ & $46(30.66)$ & $3(2)$ & $15(10)$ & $12(8)$ & $150(100)$ \\
\hline Rent seeking by influencing the public sector & $70(46.66)$ & $50(33.33)$ & $4(26.66)$ & $14(9.33)$ & $12(8)$ & $150(100)$ \\
\hline Rent seeking led by the public sector it self & $80(53.33)$ & $45(30)$ & $6(4)$ & $10(6.66)$ & $9(6)$ & $150(100)$ \\
\hline
\end{tabular}

Source: Field Survey, 2019.

\subsection{Typical Forms of Rent Seeking Prevalent in the Town}

In table 4, respondents were required to indicate the common forms of rent seeking manifested in the Town. To begin with, about $140(93.33 \%)$ of the respondents, majorities, witnessed that petty form of rent seeking behaved by lower civil servants working at different public offices is ubiquitous. Then, about $135(90 \%)$ of the respondents, the majority, replied that there are briberies made by privilegeseeking individuals (particularly traders). In congruent, an informant from the office of Justice has argued that there are explicit practices of bribery particularly in the land administration sector. The informant provided a case that there are detained civil servants in the Municipality office who received more than 200,000 Ethiopian Birr individually from rent-seeking forces so that the latter controlled plots of land illegally. Next, $120(80 \%)$ of the respondents marked that illegal lobbying practices to exert unnecessary influence on the urban decision makers particularly the local councils [to make rules and regulations in favor of the rent seeking groups] are evidently incurred. Finally, about 155 (76.67\%) of the respondents, the majorities, underlined that attempts of collusive interests where benefits shared in a very complicated and conspired manners among the actors were commonly faced forms of rent seeking in the Town. On the account of this, the survey of Municipality office on the manners of public services deliveries explicitly shows that the public satisfaction is rated to be $68 \%$ which is getting worst over time.

Table 4. Ubiquitous Forms of Rent Seeking in Adigrat Town.

\begin{tabular}{lll}
\hline Which rent reeking forms do you think common? & Options & N (\%) \\
\hline \multirow{2}{*}{ Bureaucratic corruption } & Yes & $140(93.33)$ \\
& No & $10(6.66)$ \\
Lobbying practices & Yes & $120(80)$ \\
& No & $30(20)$ \\
Bribery & Yes & $135(90)$ \\
& No & $15(10)$ \\
Actions of collusive interests & Yes & $115(76.67)$ \\
Grand Total & No & $35(23.34)$ \\
\hline
\end{tabular}

Source: Field Survey, 2019. 
In the same vein, informants from Revenue Development and Justice Offices have also proved that forms of political and bureaucratic corruption are endemic to experience in public sectors. At the grand level, it is widely observed when those who are constitutionally mandated to make inclusive decisions distort public decisions and policies merely in favor of their interests and other partners. Worth noting, an informant from peace and administration office has provided very amazing specific instance that a police member has worked in cooperation with the thieves who robbed an ox seeking the share of its total market price. One day, while the ox-owner farmer come to the police station and asked the police if he knows about the existence of ox, the police replied that he doesn't have any information of the case. This empirical case shows how far the government apparatus is being spoiled and employed for private gain purpose. In a public forum prepared by Tigrai Television, the ViceManager of Eastern Zone has also underlined that because networks of rent seeking are mushroomed to exclusively control the urban land [the center of profit of this time], preparing fertile conditions for actual and potential investors and housing services has been remaining a formidable challenge to the municipality of the town. He has provided an instance to the extent that a given urban dweller rent seeker owns about more than eleven plots of land illegally via the years long established rent seeking ropes stretched among brokers, urban planners, engineers, Kebele managers and other actors thereon. Besides, the Vice Manager added that the absences of urban land bank, Local Development Plan (LDP), and modern land tenure system have been exacerbating the scramble and conquest for the urban lands illegally by the mafia groups. From this, one can infer that despite their frequencies and intensities differ, the forms of rent seeking behaviors are widespread in the local government. In this respect, [29] has also noted that forms such as bribery, favoritism, fraud and embezzlements, illegal lobbying and state capturing misconducts are pervasive in Ethiopia.

\subsection{Levels of Rent Seeking Reflected}

As shown in the below table 5, respondents were required to rank the rent seeking levels reflected in the Town depending as per the scope of prevalence. Hence, rent seeking practice to persistently secure government position then to extract exclusive benefits is ranked first getting maximum weighted scores of 392 , or $((110 * 3)+(22 * 2)+$ $\left.\left(18^{*} 1\right)\right)$. Then, counter rent seeking to escape from the cost of deregulation/regulation measures imposed by the government is ranked second securing the weighted scores of 380 , or $((25 * 3)+(105 * 2)+(20 * 1))$. Next, rent seeking to secure privileges and distort the right flows of public services while things are going normal is ranked third obtaining the least weighted scores of 240 , or $\left(\left(35^{*} 3\right)+(20 * 2)+\left(95^{*} 1\right)\right)$. From this, rent seeking attempts to capture the public sectors machineries, escape from government regulatory and deregulatory measures, and manipulate special benefit at normal situations are prevailed. This proves the fact that in African countries, networks of political patronages have been stretched where the respective states' resources are allocated exclusively among the social, political, and economic elites. In Africa, patron-cliental relationships and neo-patrimonial connections have been prevailed being pervasive states building challenges [7]. The formal institutions are too weak to make leaders accountable to the general public instead powers are vested to maximize the interests of respective privileged patrons and supporters who dominantly constituted the system. [16] has also denoted that the fight against the institutionalized rent seeking forms is quite difficult in African LDCs. This is because in the condition where forms of rent seeking have secured institutional warranty, it is less likely to struggle against them.

Table 5. Levels of Rent Seeking Reflected in the City.

\begin{tabular}{|c|c|c|c|c|c|}
\hline \multirow{3}{*}{ Rent Seeking Levels Reflected } & \multicolumn{3}{|c|}{ Ranks and assigned weights } & \multirow{3}{*}{$\begin{array}{l}\text { Total N } \\
(\%)\end{array}$} & \multirow{3}{*}{$\begin{array}{l}\text { Final Rank } \\
\text { Based on } \\
\text { weighted scores }\end{array}$} \\
\hline & $1^{\text {st } * 3}$ & $2^{\text {nd } * 2}$ & $3^{\text {rd } * 1}$ & & \\
\hline & $\mathbf{N}(\%)$ & $\mathbf{N}(\%)$ & $\mathbf{N}(\%)$ & & \\
\hline Rent seeking to obtain government position then extract private benefits & $110(73.34)$ & $22(14.66)$ & $18(12)$ & $150(100)$ & $1^{\mathrm{st}}=392$ \\
\hline Counter rent seeking to escape from the cost of deregulation/regulation & $25(16.66)$ & $105(70)$ & $20(13.33)$ & $150(100)$ & $2^{\text {nd }}=380$ \\
\hline Rent seeking to secure privileges at normal circumstances & $35(23.33)$ & $20(13.33)$ & $95(63.33)$ & $150(100)$ & $3^{\text {rd }}=240$ \\
\hline
\end{tabular}

Source: Field Survey, 2019.

\subsection{Participants in Political Economy of Rent Seeking in the Town}

As depicted in table 6, the respondents have indicated the major participants in the political economy of rent seeking as per the order of their involvements level. Accordingly, politically appointed officials are ranked as the primary actors swimming on the ocean of rent seeking getting the uppermost weighted scores of 494 , or $(90 * 4)+(25 * 3)+$ $(24 * 2)+(11 * 1)$ points. Next, local private sectors or capitalists engaged in making profits are ranked as the second actors of rent seeking scoring 455, or $(35 * 4+80 * 3+20 * 2+15 * 1)$ points. Then, some civil servants working in their respective public sectors are ranked as the third players of rent seeking activities obtaining the total points of 367 , or $(22 * 4+38 * 3+75 * 2+15 * 1)$. Lastly, with the score of 267 , or $(22 * 4+13 * 3+15 * 2+110 * 1)$ points, other public services users and groups are ranked as the fourth and last players of rent seeking in the city. The respondents have justified that it is the political leader that often become first being a model either for good or bad then the rest followers and the governed do accordingly. Thus, the political leaders, 
capitalists, civil servants and other ordinary citizens in tandem are spraying their poisonous roles to undermine the developmental and democratic efforts of the urban administration. However, the result still indicates the organized continuation of conspiracy of benefits made between the political and economic groups who constituted the new exploitative classes of privileges.

Table 6. Respondents Indication on the Major Participants of Rent Seeking.

\begin{tabular}{|c|c|c|c|c|c|c|}
\hline \multirow{3}{*}{ Actors of Rent Seeking } & \multicolumn{4}{|c|}{ Ranks and Assigned Weights } & \multirow{3}{*}{ Total N (\%) } & \multirow{3}{*}{$\begin{array}{l}\text { Finalized } \\
\text { Ranks }\end{array}$} \\
\hline & $1^{\text {st }} * 4$ & $2^{\text {nd }} * 3$ & $3^{\text {rd }} * 2$ & $4^{\text {th }} * 1$ & & \\
\hline & $\mathbf{N}(\%)$ & $\mathbf{N}(\%)$ & $\mathbf{N}(\%)$ & $\mathbf{N}(\%)$ & & \\
\hline Politically Appointed Bodies & $90(60)$ & $25(16.66)$ & $24(16)$ & $11(7.33)$ & $150(100)$ & $1^{\text {st }}=494$ \\
\hline Private Sectors & $35(23.33)$ & $80(53.33)$ & $20(13.33)$ & $15(10)$ & $150(100)$ & $2^{\text {nd }}=455$ \\
\hline Civil Servants & $22(14.66)$ & $38(25.33)$ & $75(50)$ & $15(10)$ & $150(100)$ & $3^{\text {rd }}=367$ \\
\hline Other Service Users & $22(14.66)$ & $13(8.66)$ & $15(10)$ & $110(73.33)$ & $150(100)$ & $4^{\text {th }}=267$ \\
\hline
\end{tabular}

Source: Field Survey, 2019.

Most importantly, key informants from the Revenue Development and the Municipality offices have confirmed that the practice of illegal construction of houses is among the widely rampant crimes where a number of rent seeking actors swim together. Surprisingly, actors ranging from police members, teachers, Kebele managers, religious leaders, town council members, to other civil servants have taken part in in the attempts of building houses illegally though the amount differs. This happening meticulously indicates that land is the hub of rent seeking and corrupt practices where mafia groups exclusively plunder the people's and state's property.

In the open-ended questionnaires, majorities of the respondents have showed that their local leaders usually scramble for securing private interests overlooking the public interests. In congruent, the respondents underlined that although superficial and rhetoric public discourses to fight against rent seeking and promote inclusive political economy are common to experience, beyond the window-dressing pleasing speeches no radical and improved public services are entertained by the people. Amazingly, there are still privileged new classes [most of them are from the outstanding clans of the residents] who have never experienced delayed or denied public services in the Town administration.
As a result, most government leaders found at their respective leadership tires are political-capitalists who consider politics or public power is a business to enrich their personal wellbeing thereby they become politically and economically powerful classes. Pertaining to this, [30] has further underlined that the Ethiopian state never been blessed with committed leaders who condemn rent seeking and corrupt behaviors to make the envisaged national dreams authentic. According to him, let alone the local ones, the toplevel leaders themselves are prone to rent seeking attitudes and behaviors violating the grand democratic principle of rule of law. In a similar context, [14] on his part has also confirmed that dishonest, uncommitted and incompetent leaders who couldn't extricate the destitute and impoverished people from the quagmire of poverty and backwardness are rampant in Mekelle city in particular and Tigrai in general.

\subsection{Initial Remedies Employed to Minimize Rent Seeking in the Town}

Even though rent seeking and corrupt behaviors can't be entirely eradicated, they can be minimized and managed employing different institutional and governance apparatuses.

Table 7. Remedies Used to Minimize Rent Seeking in the Town.

\begin{tabular}{|c|c|c|c|c|c|c|}
\hline Responses to Control Rent Seeking & $\begin{array}{l}\text { Very Satisfying } \\
\text { N (\%) }\end{array}$ & $\begin{array}{l}\text { Satisfyi } \\
\text { N }(\%) \\
\end{array}$ & $\begin{array}{l}\text { Neutral } \\
\text { N }(\%) \\
\end{array}$ & $\begin{array}{l}\text { Dissatisfying } \\
\text { N (\%) }\end{array}$ & $\begin{array}{l}\text { Very Dissatisfying } \\
\text { N }(\%)\end{array}$ & $\begin{array}{l}\text { Total } \\
\text { N }(\%) \\
\end{array}$ \\
\hline Considering rent seeking the prime public sectors' agenda & $15(10)$ & $20(13.33)$ & $4(2.66)$ & $90(60 \%)$ & $21(14)$ & $150(100)$ \\
\hline Massive awareness creation and public-wide deliberations & $4(2.66)$ & $36(24)$ & $3(2)$ & $80(53.33)$ & $27(18)$ & $150(100)$ \\
\hline Regular evaluations on directives and actions performance & $5(3.33)$ & $22(14.66)$ & $3(2)$ & $100(66.66)$ & $20(13.33)$ & $150(100)$ \\
\hline Stakeholders involvement in decision making process & $7(4.66)$ & $23(15.33)$ & $2(1.33)$ & $95(63.33)$ & $23(15.33)$ & $150(100)$ \\
\hline Taking Legal measurement & $10(6.66)$ & $15(10)$ & $5(3.33)$ & $85(56.66)$ & $35(23.33)$ & $150(100)$ \\
\hline
\end{tabular}

Source: Field Survey, 2019.

As depicted in table 7, respondents were required to indicate their level of satisfaction with the ongoing remedies used to control rent seeking attitudes and behaviors in the Town. First, concerning with the endeavor to mainstream the agenda of fighting socially wasteful rent seeking in government offices, the majorities, $111(74 \%)$ of the respondents were dissatisfied. Second, pertaining to the attempts of undertaking massive awareness creation and regular public-wide discussions forums, the majorities, 107 (71.33\%) of the respondents were dissatisfied. Third, with respect to the maneuver of conducting consistent monitoring and evaluations on the local directives and actions, the majorities, $120(79.99 \%)$ of the respondents indicated their dissatisfaction. Fourth, regarding the Town administration's commitment to work concertedly with important stake holders such as media, civil societies, political parties, religious institutions and other civic formations, 118 (78.99\%) of the 
respondents responded that they are dissatisfied by implying a lot remains to be done further. Then, 143 (79.4\%) of the respondents were dissatisfied by the enforcement of legal measurement up on the actual rent seekers. Lastly, 129 (86\%) of the respondents were dissatisfied by the reform to use ICT during the day to day activities of the government offices.

Similarly, informants have evidenced that it is common to observe when a politically affiliated rent seeker remains innocent on the dishonest reason that evidences were not found during the initial processes of the suspected cases investigation. This denotes that even though there are perpetrators of the crime related to rent seeking but evidences lack since the action doers have already established invisible and intricate ropes of networks concealing the facts behind, the official game. More importantly, it has been argued that the current fight against rent seeking is largely stressed on "branches letting the unhealthy stems and roots uninvestigated". In most cases, the commitment to clear misconducts don't begin from the top political leaders and capitalists but from the insignificant rent seeking and corrupt practices made by the lower bureaucrats and subsistence based traders, said the informants. This kind of local governance practice inevitably precipitates crony capitalism and the risks of public sector-capture where the poorer gets poorer and the richer gets richer from time to time.

Most surprisingly, being asked to reflect about the existing trends of fighting against the rent seeking practices manifested in the Town, an informant from the civil service office of the Town has stated his position as below:

"I,......for instance, can't expose the rent seeking behaviors made in my working environment because there are no impartially enforceable legal and administrative guarantees up on the one who wants to act as a democratic citizen. For that matter, the rent seeker is doing such malpractice being fully confident on the hidden political back up that he/she has behind. But I, the destitute citizen, who lead the starved family haven't the grantee of not being faced with any life consequences imposed from other networked rent seeking forces after my whistle blowing of the wrong doings committed. Oh...!! I want to grow up my children through my pure monthly salary. For that reason, usually I tend to remain silent and tolerate rent seeking practices observed in the Town".

In the same vein, informants confirmed that initial institutional remedies such as shuffling of public-position holders and imposing legal and disciplinary measurements have been continuously taken despite newly formed rent seeking networks are rapidly increasing hitherto. Surprisingly, it is widely experienced that those suspected and actual perpetrators of rent seeking and corrupt practices are promoted to a very fascinating public position than they had before. Nevertheless, few informants from the Civil Service Bureau of Tigrai Region and Town administration have reacted that principles of meritocracy and professionalism are fairly being applied in public sectors by which the local governments minimize rent seeking practices among others. Moreover, they denoted the timely introduced consecutive innovative public management reforms such as the civil service reform, responsiveness oriented-Business Process Reengineering (BPR), efficiency based-Balanced Scored Card (BSC), preparing suggestion boxes, citizen charters, weekly and monthly evaluations, Kaizen and recently Job Evaluation and Grading (JEG) are positively contributing to the delivery of quality public services so that rent seeking attempts are being eventually controlled. Needless to say, during the consecutive revival measures and processes, attempts have been made to place both politically matured and academically competent individuals to relevant leadership positions, said the informants.

On the other side, informants have argued that the community is still promoting the traditionally entrenched erroneous assumption that a given quality public service couldn't be entertained in the conditions where some kinds of rent seeking activities are absent. In congruent, an informant from the Municipality office illustrated a case where groups of privileged service-seekers have flagrantly searched the bank account of a public-servant working in the Urban Land Development and Administration Core Process and credited him some amount of money pushing him to be actor of rent seeking and corrupt practices unwillingly. This shocking action of the influencing groups leads to conclude that there is community held perverted assumption that quality government service is solely enjoyed via making the respective public official salivated of unconditional amount of money. This coincides with Tullock's (2000) cited in [21] assertion that "People are always People" who need to secure their exclusive interests without caring about the wellbeing of rest section of the society.

Undeniably, on the part of the community, there are initial attempts to whistle blow some misconducts committed either by government bodies or other actors but not supported by plausible and coherent evidences. Worst of all, attempts of false whistle blowing aimed at revenging for somebody who is not in a good relationships with the whistle blower have also been sometimes experienced problems of the Town. Furthermore, the urban administration is reluctant to strengthen the local communities based organizations, civic associations and the media institutions to concertedly crusade over rent seeking attempts. Worth mentioning, the periodic directives, rules and regulations made are far from the quick reach of the community as immediate as their enactment and are also inconsistent each other exacerbating chances for lacunas in the implementation stages. Fundamentally, the Town administration's bureaucracy is neither free of private interest-pressures nor institutionally connected with the vast community to galvanize and enhance legitimacy, negotiations and mutual communications. [2] study on the responsiveness and transparency in Mekelle City's Municipality also reflected the same fact that the political leaders and civil servants are not politically and academically vibrant, uncommitted, and generally prioritize their personal to public interests being immersed themselves in the rent seeking and corrupts oceans. Thus, both the local government and community are not as vigilant and cooperative as possible to fight against rent seeking. 


\section{Conclusion and Recommendation}

\subsection{Conclusion}

In this paper, an assessment has been done on the prevalence of political economy of rent seeking and the remedies employed to minimize it in Adigrat Tow local governance. Accordingly, the public sectors' failures to steadily respond for recurrent needs of the people, institutional and legal lacuna, prevalence of materialistic and self-centered motives, rampant mutual mistrusts, historical situations, patrimonial relations and policy gaps have been entrenched as the major causes of the culture of rent seeking in the Town. On the account of this fact, rent seeking practices via individual negotiations, established favor-seeking groups, and sometimes public sectors-led (institutionalized) rent seeking situations have been experienced in the Town. In connection, rent seeking forms such as bribery, bureaucratic corruption, illegal lobbying and collusive interests are endemic to the Town. Rent seeking levels to personalize the local government apparatus, resist situational government regulatory and deregulatory practices, and control exclusive privileges while other things remained constant have been faced though their degrees of occurrences differ. Besides, it has also been revealed that actors such as the political leaders, private sectors, civil servants, and other individuals played their poisonous roles in exacerbating the dominance of rent seeking in the Town. This fact implies that a great deal of people have been engaged in the practices of rent seeking where the plundering of all against all urban situation rampant. Under such local governance circumstances ensuring social transformation is a nightmare.

With respect to the community participation, administration gaps have been accompanied to effectively mobilize the people and made them intolerants of rent seeking attitudes and behaviors. Nevertheless, embryonic moves to mainstream the struggle against wasteful rent seeking, create awareness, deliberate on policy implementation, enforce legal instruments, involve stakeholders in making decisions, and provide ICT backed services have been initiated. To sum up, there are no ground breaking and unprecedented rent seeking-cleaning processes as widely promised as possible.

\subsection{Recommendations}

On the basis of the findings, the following institutional and governance related practices are recommended to the respective urban administration as follows:

Important decisions should be made as per the very demands of the grass root people. The involvement of the people and other essential stakeholders such as the local council, civic associations, and media institutions in the processes of decision making should be the common practices of the local government. Beyond this, organized and concerted endeavors should be done to galvanize the people to condemn rent seeking and corrupt practices.
The public sectors of the Town should set the common areas where they can do in tandem to minimize the propensity of rent seeking practices. Besides, they should enhance the culture of their mutual communication by which they can contain attempts of externalizing accountabilities and governance failures. More particularly, the corruption and rent seeking prone offices should establish especial task forces assigned for investigating the major causes of rent seeking so that put remedies and work over the issues persistently.

Anti-rent seeking strategies and institutions should be strengthened. Strict legal measurements should be imposed on the actual perpetrators of rent seeking irrespective of their political and economic positions to deter potential criminals. Particularly, the police, public prosecutors, ethics and anticorruption agents should cooperatively and neutrally prevent and investigate cases of rent seeking practices. Public sectorlevel ethics offices and citizen charters should be structured to independently prevent and control misbehaviors. Apart from this, the indigenous values and norms of the local community which enhance social capital should be restored via concerted efforts. Finally, Information and Communication Technology should be employed during the local government services particularly in the municipality office of the Town.

The marriage between political and administrative functions should be divorced. Public sectors and their respective bureaucrats should autonomously make public decisions. Meritocratic and politically insulated bureaucracy ensures positive change and resists rent seeking inclinations. This is because in the condition where the bureaucracy is not filled and staffed by highly competent and politically neutral public servants, inescapably the political economy of rent seeking becomes overriding.

Private sectors on their part should act cooperatively and productively. They should be free of forming collusive interests with the key executive and political bodies of the government. This is because opportunistic network unavoidably creates crony capitalism where resources are distributed solely among the tacitly formed exploitative factions. Hence, the simultaneous achievement of these institutional and governance endeavors make the socially wasteful rent seeking cleaning process realistic. Doing all these, the widely entrenched coordination problem which is equated with the traditional saying which goes on "when others plunder your father's home property, loot it with them too" can thus reduce significantly in Adigrat Town in particular and the state in general.

\section{References}

[1] Abdi, A, A., Ellis, L, and Shizha, E. (2005) Democratic Development and the Role of Citizenship Education in subSaharan Africa with a case focus on Zambia. International Education Journal, 2005, 6 (4), 454-466.

[2] Abrha, F, W. (2016) Assessment of Responsiveness and Transparency: The case of Mekelle Municipality. Journal of Civil Service and Legal Sciences vol. 5: 191. 
[3] Ackerman, S, R. (1996) High-Level Rent Seeking and Corruption in African Regimes: Theory and Cases, Yale University.

[4] Addis Alem, B. (2014) Democracy and Economic Development in Ethiopia. The Red Sea Press.

[5] Aligica, P. D and Tarko, V. (2014) Crony Capitalism: Rent Seeking, Institutions and Ideology. KYKLOS, Vol. 67, No. 2, 156-176, USA.

[6] Amaha, D, T. (2012) The Impact of State Policies And Strategies In Ethiopia's Development Challenge: Master's Thesis, University of South Africa.

[7] Arriola, R, L. (2009) Patronage and Political Stability in Africa. Comparative Political Studies. University of California, Berkeley.

[8] Befekadu, W. (2013) EPRDF, Developmental State, and Rent Seeking. University of Utah: Available at: www.meleszenawi.com/.../Ethiopia-EPRDF-DevelopmentalState-and-Rent-Seeking.pdf [Accessed on Sep/12/2016].

[9] Bichaka, F. (1992) Rent Seeking Behaviors of the Ethiopian Rulers as a Constraint for the economic Development of the Oromo People. Oromo Commentary. Vol. II, No, 1.

[10] Blankart, C. B and Ehmke, D. C. (2015) Overcoming the Rent-Seeking Defect in Regional Policy: Time to Re-think the Institutional Design. CESifo DICE Report 3/2015, University of Berlin.

[11] Brinkerhoff, D, W. and Goldsmith, A, R (2002) Clientelism, Patrimonialism and Democratic Governance: An Overview and Framework for Assessment and Programming. Abt Associates Wheeler Street, Cambridge.

[12] Congleton, R. (2002) Rent Seeking and Political Institutions: Forthcoming in the Encyclopedia of Public Choice. Georege Mason University.

[13] Demirbas, D. (1999) Rent-Seeking In Developed And Developing Countries: Cross Section And Time Series Studies. University of Leicester.

[14] Desta, H, H. (2016) Euphemism for Corruption in Ethiopia. Norway, Oslo: Available at: http://aigaforum.com/article2016/Euphemism_for Corruption in Ethiopia.pdf.

[15] Federal Democratic Republic of Ethiopia: National Development Planning (2015) The Second Growth and Transformation Plan (GTP II) of 2015/16-2019/20. Addis Ababa, Ethiopia.

[16] Fisher, P. (2005) Rent-Seeking Institutions Reforms In Africa: Theory and Empirical Evidence for Tanzania. PhD Thesis submitted to the University of Konstanz, Germany.

[17] Garfield, R. (1996) Rent Seeking Hobbles Economic Growth. Joint Economic Committee Republicans.

[18] Gashaw, A., Endalcachew, B., and Zelalem, M. (2015) Cause and Consequences of Corruption in Ethiopia; The Case of Ambo Town. Journal of Educational Administration and Management.
[19] Habtamu, A. (2014) Ethiopia's Context of Rent Seeking Behavior: Sociological Perspectives. Available at: http://aigaforum.com/articles/rent-seekingbehavior.pdf[Accessed on November, 17/2016].

[20] Hill, P, J. (1999) Public Choice: A Review. Faith \& Economics-Number 34-Fall 1999. p 1-10.

[21] Hillman, A, L. and Ursprung, H, W. (2000) Political culture and economic decline. European Journal of Political Economy Vol. 162000 189-213.

[22] Hillman, A, L. (2010) Rent seeking. The Elgar Companion to Public Choice, $2^{\text {nd }}$ edition: In Michael Reksulak, Laura Razzolini, William F. Shughart II. Bar-Ilan University, Israel.

[23] Khan, M, H. (2000) Rent Seeking as Process: Theory and Evidence in Asia. Cambridge University Press.

[24] Khwaja, A, I. and Mian, A. (2011) Rent Seeking and Corruption in Financial Markets. Annual Review of Economics Online.

[25] Kelsall, T. et al. (2010) Developmental patrimonialism? Questioning the orthodoxy on political governance and economic progress in Africa. A Working Paper No. 9. African Power and Politics.

[26] Kruger, A, O. (1974) The Political Economy of the Rent Seeking Society. American Economic Review.

[27] Lambsdorff, J, G. (2002) Corruption and rent-seeking. Public Choice 113: 97-125, 2002. Kluwer Academic Publishers, Netherlands.

[28] Latkov, A. (2014) Trends of Rent-seeking Theory. Munich Personal RePEc Archive. Saratov, Russia.

[29] Lindner, S. (2014) Ethiopia: Over View of Corruption in Administration. Transparency International.

[30] Mesgna, G. (2015) The Challenges and Prospects of Building Developmental State in Africa: A Comparative Study of Botswana and Ethiopia. Addis Ababa, Ethiopia.

[31] Ministry of Civil Service (2013) Rent Seeking: Essence, Behaviors, and Controlling Mechanisms. Federal Democratic Republic of Ethiopia, Civil Service Transformation Research Center, Addis Ababa, Ethiopia.

[32] Ministry of Finance and Economic Development (2010) Growth and Transformation Plan of 2010/11-2014/15. The Federal Democratic Republic of Ethiopia. Addis Ababa, Ethiopia.

[33] Ridenour, C. S. and Newman, L. (2008) Mixed Methods Research: Exploring the Interactive Continuum, Southern Illinois University, USA.

[34] Rowley, C, K. (ed). (2005) The Rent Seeking Society. $1^{\text {st }}$ ed. Liberty Fund, USA.

[35] Zelalem, G. (2015) Concerted Effort Instrumental in Corruption Battle. The Ethiopian Herald News Paper, 18/Dec. Page 1, vol. no 084, Addis Ababa. 